\title{
Equatorial
}

Dossiê: Etnografando experiências do adoecimento e medicalização no Brasil

\section{Biomedicina, gestão do tratamento e desencantos: experiências de mulheres soropositivas no Rio de Janeiro}

\author{
Romário Vieira Nelvo \\ Mestrando em Antropologia Social \\ Museu Nacional, Universidade Federal do Rio de Janeiro \\ nelvo.romario@gmail.com
}

\section{RESUMO}

Com o avanço das tecnologias biomédicas para o tratamento do HIV/Aids, a qualidade de vida tornouse uma possibilidade vital para a pessoa portadora, contrariando o cenário da década de 1980, quando o diagnóstico era como uma sentença de morte. Por outro lado, tornar-se soropositivo requer mudanças numa série de hábitos cotidianos, os quais medicar-se diariamente é parte desse processo. Neste artigo, analiso os efeitos colaterais, sociais e subjetivos decorrentes da medicalização e gestão do tratamento em trajetórias sociais. Interessa aqui, o entrelaçamento entre histórias de vida e a materialidade e concretude das drogas farmacológicas. Para tanto, lanço mão da análise antropológica da trajetória de três mulheres e mães jovens soropositivas, oriundas das camadas populares da cidade do Rio de Janeiro. A partir de infraestruturas concretas de como as pessoas gestam o tratamento na tessitura de seus cotidianos, têm sido possível compreender ambiguidades e limites da biomedicina como cultura global, uma vez que os medicamentos para elas acarretam processos de significação da experiência, momentos de inflexão e sentimentos de prisão. Assim, suas experiências materializam os efeitos reais das tecnologias sobre efetuações de desencantos terapêuticos na gestão do tratamento de HIV/Aids, além de abrir margem para pensar a respeito dos medicamentos para além da chave analítica da liberdade e do encanto numa Cosmovisão ocidental.

Palavras-chave: Biomedicina, Tratamentos, Antropologia da Saúde, HIV/Aids, Medicamentos.

\section{Introdução}

Neste artigo analiso os efeitos colaterais, sociais e subjetivos decorrentes da medicalização e gestão do tratamento, em trajetórias sociais vistas a partir do fluxo relacional da pessoa com os remédios (BIEHL, 2008, 2011). Ou seja, interesso-me pelo entrelaçamento entre histórias de vida com a materialidade e concretude das drogas farmacológicas, a fim de compreender experiências de significação da realidade, momentos de inflexão e dramatização 
do cotidiano bem como as ambiguidades no conjunto de valores de curas e encantos dos medicamentos numa Cosmovisão ocidental (AZIZE, 2002, 2012; VAN DE GEEST e WHYTE, 2011; MANICA, 2012). Para tanto, lanço mão da análise antropológica das práticas cotidianas, com as quais três mulheres e mães jovens soropositivas, oriundas das camadas populares da cidade do Rio de Janeiro, defrontam-se com o uso de seus medicamentos diários - que aparecem contornados pelos sentimentos de prisão e fardo em suas trajetórias, e não como algo que as proporcionam liberdade.

A epidemia de Aids surgiu na década de 1980, causando fortes controvérsias às práticas e saberes biomédicos (VALLE, 2010). No decorrer de sua produção enquanto uma epidemia construída sob imagens do estigma e ideias corporais e simbólicas associadas à morte (SONTAG, 1989; DANIEL e PARKER, 1991; MONTEIRO et al., 2016), as respostas biomédicas são encaradas pelas pessoas, como Valle (2010) demonstra em sua análise, ora com desconfianças, ora como uma via coletiva, pessoal e, ao mesmo tempo, possível para a vitalidade. Segundo o autor, isso pode acarretar em escolhas, às vezes, de reprovação do tratamento convencional por formas alternativas, em decorrência de traumas, medos e estigmas advindos da imagem negativa da Aids. Por outro lado, o aumento da expectativa de vida, para a pessoa vivendo com HIV/Aids, é um marco importante das tecnologias médicas (VALLE, 2010; BIEHL, 2011).

A partir da vigência da Lei no 9.313 do ano de 1996, em âmbito nacional, o Brasil passou a incorporar o tratamento antirretroviral de forma gratuita e universal em seu Sistema Único de Saúde (SUS). Mesmo que o tratamento já tenha tido um recorte de classe e raça, uma vez que, no início da epidemia, os popularmente conhecidos como coquetéis deveriam ser comprados e em preços demasiado altos. Com a distribuição gratuita em questão, há uma possibilidade concreta de qualidade de vida. Assim, como muito bem Valle (2010) e Biehl (2011) já haviam sugerido, os medicamentos inserem-se em uma cultura global do imaginário do bem-estar biomédico, para o HIV/Aids. Em meu estudo etnográfico, as substâncias medicamentosas, que as interlocutoras faziam uso, ocupavam lugares centrais em suas dinâmicas micropolíticas de parentesco, conjugalidades e, sobretudo, em momentos de inflexão durante a gestação, significação da realidade e nos atos diários, que reverberavam em uma série de dificuldades e limites das formas mais amplas dos processos biomédicos, além de facilitarem o processo de identificar seus lugares no mundo e suas condições e ações sociais da pessoa (NELVO, 2017).

Para a presente análise, empreendo os ensinamentos dos antropólogos Van der Geest 
e Whyte (2011), para compreender acerca da importância de os medicamentos serem bons para pensar em antropologia. Segundo os autores, os medicamentos facilitam processos culturais e comunicam maneiras tais como os ocidentais os acionam por conta da leitura de seus encantos e liberdade. A concretude dos medicamentos permite tomar suas substâncias como formas de materializar e tangenciar a cura. Portanto, são circunscritos numa ordem social e cultural valorativa, nos quais os poderes disciplinar, biomédico e científico são operantes (FOUCAULT, 1987). Por outro lado, foi localizado nas narrativas das minhas interlocutoras um amplo processo relacional quanto à gestão cotidiana de seus tratamentos com medicamentos via oral, que penso ser possível que seja lido a partir da chave analítica, a princípio, não dos seus encantos - mesmo que a qualidade de vida e outras vantagens sejam relativizadas e valorizadas por elas - mas, sim, pela capacidade existencial, concreta e fenomenológica de gerar desencantos terapêuticos, os quais comunicam as ações sociais da pessoa. Desse modo, o que se espera mostrar ao longo deste artigo são exemplos empíricos e subjetivos da relação paradoxal da biomedicina como cultura global na tessitura das experiências terapêuticas (BIEHL, 2011).

Com os dados de campo em questão, espero contribuir para os estudos em Antropologia da Saúde. Campo que explora, entre outras coisas, formas de adoecimentos, tratamentos e curas (ALVES e RABELO, 1998). Fleischer e Ferreira (2014), ao formularem questões acerca da etnografia efetuada em serviços de saúde, argumentam que "não é possível padronizá-la, ao contrário, devemos aceitar o seu caráter inesperado, para que seus riscos e desafios possam sempre nos surpreender" (p. 13). Compreendo que, por um lado, minha pesquisa fala sobre práticas de saúde, contudo, por outro, não foi realizada junto às interlocutoras, em serviços de saúde. Todavia, creio que o que define as autoras nos serve para refletir sobre a validade das histórias que analiso como sendo capazes de revelar nuances e cálculos cotidianos acerca de processos de saúde/doença, mesmo que fora dos espaços hospitalares. No caso das interlocutoras, o caráter "inesperado" comunica uma cartografia humana, ou seja, zonas relacionais que tecem os seus cotidianos. O movimento que proponho é refletir sobre como as pessoas gestam o tratamento para uma infecção crônica tendo como base a análise dos medicamentos como tecnologias da biomedicina como cultura global (VALLE, 2010). Próximo do que fez Biehl $(2006,2011)$ em sua etnografia com sujeitos portadores de HIV / Aids no fim da década de 1990 e início dos anos 2000, espero mostrar que as formas de tratamentos terapêuticos para pessoas soropositivas inserem-se em fluxos dinâmicos de redefinição da vida. No caso da pesquisa supracitada de Biehl, o processo de saúde/doença e tratamento dos seus interlo- 
cutores traz à tona um tipo de bricolagem de vida, pois "atravessando mundos de risco e escassez, limitadas sem serem totalmente sobredeterminadas, as pessoas criam pequenos e passageiros espaços, através e além de classificações e aparatos" (BIEHL, 2011, p. 271). A partir do meu estudo etnográfico, espero mostrar que não há uma naturalidade no processo do medicar-se. Há um encontro da pessoa com os medicamentos que traz muitas situações "inesperadas", cujas interlocutoras lidam com elas lançando mão de processos de significação da realidade. São nesses atravessamentos de bricolagem de vida (BIEHL, 2011), que a etnografia em questão contribui para o campo antropológico da saúde.

Uma série de dificuldades, trocas constantes, efeitos colaterais manifestados no corpo durante a gestação, sentimentos de prisão e abandonos dos medicamentos foram identificados com as histórias das interlocutoras. O que, cada vez mais, tem me permitido sugerir outra leitura para o encanto dos medicamentos, a qual será central neste artigo, tecida por infraestruturas concretas de desencantos à luz das experiências das interlocutoras. Em outras palavras, o entendimento da prática diária da medicação, que acarreta uma mudança significativa para as pessoas soropositivas em seus processos de tornar-se soropositivo (VALLE, 2010), deve atentar, sugiro, para a conformação social e relacional das formas de conceber o espirito bumano, o "eu"; a noção de pessoa (MAUSS, 2015). Não obstante, as relações familiares, os projetos de maternidade e a imagem associada aos medos e dificuldades quanto à condição de doença do HIV/Aids não são meros dados de campo, mas centrais para o presente movimento que analisará o encontro biográfico das pessoas com os remédios ${ }^{1}$. Assim, divido o artigo em quatro partes seguidas de uma consideração final.

Em um primeiro momento, visualizo o processo de construção da etnografia e os pressupostos ético-morais que a conforma. Posteriormente, falarei sobre as maneiras segundo as quais os medicamentos para as pessoas soropositivas são vistos como tecnologias biomédicas e científicas, apoiando-me sobretudo nos ensinamentos de Valle (2010). Assim, em um terceiro momento, abrirei margem, para refletir sobre os apontamentos teóricos ao que se propõe este estudo etnográfico em termos de uma antropologia da saúde, da pessoa e experiências de gestão de tratamentos terapêuticos (VALLE, 2010; BIEHL, 2011; BRUNER, 1986; RABELO et al., 1999; AURELIANO, 2012), e como os "limites" dos encantos dos medicamentos formam as ações sociais e a condição de pessoa e saúde delas. Por fim, apresentarei as narrativas das interlocutoras quanto aos medicamentos e as analisarei pela leitura da experiência, aludindo sua capacidade existencial de gerar desencantos terapêuticos - em oposição ao encanto tal qual eles são concebidos na Cosmovisão ocidental (VAN DER GEEST 
e WHYTE, 2011). Sugerindo, portanto, a articulação ambígua e paradoxal de que falava Valle (2010) sobre a biomedicina como cultura global e os contextos locais dos processos sociais. Aqui, aparecerão formas de significação da realidade, momentos de inflexão, sentimentos de fardo e prisão e dramatização dos seus atos quanto à gestão do tratamento, o que só foi possível porque os seus medicamentos estavam "menos em suas moléculas e naturezas, e mais em seus fluxos; mais em invenções do que descobertas; mais em usos, consumos, negociações, circulações, do que simplesmente prescrições" (AZIZE, 2012, p. 135).

\section{A etnografia e o pressuposto ético-moral}

O trabalho de campo, que alicerça esta etnografia, foi inicialmente realizado no primeiro semestre do ano de 2016 e mais bem tecido nos meses de dezembro daquele ano e abril de 2017. A pesquisa enfocou nas trajetórias de Luana, Suelen e Luíza². Elas tinham entre 20 e 25 anos, são moradoras da zona oeste da cidade do Rio de Janeiro, mães e portadoras do vírus da Imunodeficiência Humana (HIV), causador da Imunodeficiência Adquirida (AIDS). A gravidez delas resulta de relações de namoro até então estáveis, entre quatro e seis anos de duração. Seus namoros vieram ao fim assim que seus filhos nasceram. Duas delas, Luana e Luíza, são soropositivas por meio de infecção vertical, quando, de forma resumida, a pessoa nasce com o vírus. A principal via de transmissão ocorre no momento do parto ou mesmo no pós-parto, por contatos com fluidos corporais, como o sangue e o leite materno. Das interlocutoras, Suelen foi a única que adquiriu o HIV por meio de relações sexuais desprotegidas. Quando a conheci, ela tinha o seu diagnóstico havia seis anos.

A pesquisa de campo começou quando visitei, durante cinco meses consecutivos, os encontros da Rede de pessoas que se autodenominam jovens vivendo e/ou convivendo com HIV/Aids do estado do Rio de Janeiro. O espaço é denominado por Rede Jovem Rio + e é comumente chamado de Rede pelas pessoas, organizado por sujeitos soropositivos desde o ano de 2009. Através do Renato, um dos membros da Rede, fui apresentado às interlocutoras desta etnografia. O estudo com as três contou com observação em campo, achados na internet sobre o assunto, conversas pelo aplicativo de mensagens instantâneas, Whats $A p p$, bem como entrevistas em profundidades com o gravador, sempre negociado ${ }^{3}$. Os encontros com todas deram-se, inicialmente, em locais abertos, como Shopping Center e praças de bairro. Posteriormente, fui convidado ao chá de bebê de uma delas, que estava no processo da segunda gestação e conheci a casa e a família de outra. Assim, essa pesquisa contou com o afinco constante da construção de confiança, tanto no dia do primeiro encontro em que foram realizadas as entrevistas, quanto posteriormente, naqueles encontros não programados e nos 
convites para conversas, seja sobre os temas da pesquisa, seja sobre quaisquer outros assuntos.

Com uma delas, Luíza, estabeleci um laço maior de amizade - o que ficará evidente nas considerações finais deste artigo. A proximidade física de nossas residências facilitou o deslocamento para os encontros durante o trabalho de campo naqueles meses e mesmo hoje em dia. Em suma, morávamos no mesmo bairro quando esta pesquisa foi construída. Como eu estava inserido numa Rede de jovens que vivem com HIV/Aids, isso me permitiu observar outros espaços tais quais eventualmente minhas interlocutoras circulavam, bem como compreender melhor o mundo social contemporâneo do HIV/Aids, sobretudo da conformação do jovem soropositivo (CUNHA, 2011). Também, compareci a eventos acadêmicos e jurídicos em âmbito nacional, mas com pressupostos universalizadores dos debates, cujos temas primordiais eram as discussões sobre direitos, discriminação e criminalização do HIV/Aids (Rio de Janeiro, Sede da Ordem dos Advogados em abril de 2016)4. Assim, essa circulação etnográfica possibilitou não somente conhecer outras pessoas soropositivas, mas também pesquisadores e profissionais de saúde. Neste sentido, acredito ser esta uma etnografia em movimento ou quem sabe multi-sited nos termos definidos por Marcus (1995).

Mesmo que a circulação para obtenção de informações seja parte da etnografia, até mesmo para as reflexões que foram geradas, optei por centrar em uma análise mais localizada nas pessoas. A intenção era compreender os temas que rodeavam os debates mais amplos sobre o HIV/Aids a partir de uma perspectiva que visasse contradições e histórias localizadas em três interlocutoras principais. Me apoio principalmente nas formulações de Abu-Lughod (1993) acerca do potencial que histórias de vida tecem narrativas sociais e, por vezes, contra culturais. Além do que, a distância fundadora da antropologia, o nós - entendido pelo pesquisador - e o eles - os informantes da cultura da qual falamos - bem como informantes do sexo e gênero masculinos, poderiam ser corroborados à luz das trajetórias das mulheres deste estudo. Dito isso, espero também com o trabalho etnográfico realizado com "algumas pessoas", localizá-las a partir da perspectiva de Biehl em sua etnografia com uma "única pessoa", para quem:

O trabalho empírico e longitudinal com uma única pessoa tem o potencial de revelar não apenas as nuances que informam a formação de famílias, comunidades e seus sistemas de valores, mas também o modo como estes encontram-se imbricados em processos macroestruturais. (BIEHL, 2008, p. 419)

Adotando tal maneira de etnografar uma única vida, o autor refletiu sobre a farmacentica- 
lização da saúde mental no Brasil e os seus efeitos colaterais, sociais e subjetivos que fez surgir a categoria social do "abandono" na trajetória de Catarina, tida como um caso de tratamento que não deu certo por sua "ex-família". Abandonada à morte, como uma até então doente mental, a interlocutora do autor encontrou na escrita o potencial de criação e do desejo da experiência de vida. Baseando-se em Deleuze, e tomando o caso de Catarina em específico, Biehl afirma que:

Pesquisas etnográficas atentas a pessoas de carne e osso movimentam-se entre infraestruturas concretas e em tempo real, registrando as particularidades de cada situação. Indo além de pressupostos universalizadores, a etnografia pode trazer a público os cálculos e interações por meio, dos quais as possibilidades da vida são limitadas, além de iluminar rumos alternativos abertos por novos desejos. (BIEHL, 2008, p. 423).

Creio que com estes ensinamentos explicitados, seja possível aplicar a reconocibilidad ontológica da pessoa de que tanto fala Butler (2009). Para a autora:

\begin{abstract}
Se o reconhecimento caracteriza um ato, uma prática, ou mesmo um cenário entre sujeitos, então, o "reconocibilidad" caracterizará as condições mais gerais, que preparam ou modelam um sujeito para o reconhecimento; os termos, as convenções e as normas gerais atuam a sua própria maneira, fazendo com que um ser humano se converta em um sujeito reconhecido, embora não sem falibilidade ou sem resultados antecipados. (BUTLER, 2009, p. 19, tradução minha).
\end{abstract}

Para o presente exercício de visibilizar as interlocutoras e seus fluxos relacionais na gestão de seus tratamentos com medicamentos, oriento-me na concepção da autora de vinculação ético-moral (BUTLER, 2009, 2011). A síntese crítica da autora, em total contexto midiatizado, que supostamente não nos permite estabelecer vinculação com o outro, é aquela, ao contrário, que nos liga eticamente à alteridade, entendendo esse outro como pessoa marcada por vidas precárias. Esse reconhecimento dá-se quando o cientista percebe a humanidade do interlocutor sob constante ameaça e reconhece o próprio outro, por sua vez, como pessoa. Dada essa capacidade de humanizar e/ou desumanizar a alteridade, o que percebi, a partir de Luana, Suelen e Luíza, foram constantes processos relacionais que ora vulnerabiliza a pessoa, ora faz emergir formas morais e emocionais de resistências e agências (ORTNER, 2007) mesmo nas experiências qualificadas por elas como sendo fracassadas nos atos da medicação.

Para o que se segue, procurarei analisar antropologicamente os desencantos terapêuticos dessas mulheres, por contornos subjetivos de precariedades. Parece paradoxal que o reconhecimento ontológico delas como pessoas, por minha parte enquanto pesquisador, tenha 
surgido das formas cotidianas de como gestam a terapêutica em suas vidas, de relatos nos quais elas justamente demonstravam não estarem bem quanto às substâncias medicamentosas. Talvez, o processo de significação e o sentimento de prisão dos medicamentos como me contaram, seja a concretude central para que eu pudesse estabelecer o reconhecimento de suas vidas, e essas narrativas de desencantos aqui em questão materializam suas precariedades.

\section{Das tecnologias biomédicas às experiências de gestão do tratamento}

Valle (2010) discorreu acerca de a biomedicina desempenhar um elemento crucial nas práticas e ideias que as pessoas soropositivas têm sobre seus corpos. Segundo o autor, esse movimento borra as fronteiras de culturas nacionais e abre-se para um movimento mais global de cuidado e bem-estar. Em outras palavras, a testagem anti-HIV e a mudança numa série de hábitos de rotinização de exames e medicação para a gestão terapêutica é uma parte mais geral da biologização do bumano, cujo centro da questão são valores e representações de saúde e doença à luz da biomedicina como uma cultura global. O tratamento para o HIV/Aids é uma tecnologia biomédica e, portanto, faz parte de uma cultura global de valores no campo da saúde (BIEHL, 2011).

Neste sentido, a análise antropológica deve atentar para quando o global encontra o local-pessoal. É assim que pode-se entender a testagem anti-HIV como "parte importante de uma complexa mediação entre formas diferentes de entendimento cultural de uma sociedade mais ampla e formas particulares de conhecimento sobre HIV/Aids" (VALLE, 2010, p. 39). Em seu estudo etnográfico, a fim de compreender o mundo social da Aids no Rio de Janeiro, o autor sugeriu que tornar-se soropositivo é uma articulação com um conjunto mais amplo de ideias, valores e representações (VALLE, 2002, 2010). As tecnologias biomédicas, como a testagem, consultas periódicas, exames e tratamentos acabam tornando-se mediações centrais de um processo de construção identitária. Assim, haja vista uma série de etapas contínuas de rotinização e monitorização do corpo, pessoas soropositivas constroem-se em meio ao que ele denomina por Identidades Clinicas. É deste modo, que a categoria biomédica técnica, soropositivo, torna-se identidade social por meio das quais "pessoas e indivíduos seriam associados, classificados e culturalmente representados" (VALLE, 2010, p. 40). Assim, ser soropositivo refere-se à construção particular de "categorias, imagens, representações culturais e discursos sobre a soropositividade, que têm sido produzidos por meio de uma combinação de forças sociais e culturais de origens e formação amplamente diferenciadas" (p. 40).

Se as tecnologias biomédicas ocidentais são fundamentais para o mundo social do 
HIV/Aids, há modos particulares e contextualmente localizados de ordenação e reordenação da circulação desses saberes e valores. O próprio autor sinaliza a expectativa ambígua quanto às utilizações das tecnologias, que, por um lado, produz bem-estar e, por outro, traz ansiedades para cada exame periódico e eventuais estigmas advindos tanto da prática do medicamento em si, sobretudo, na esfera doméstica, quanto dos seus efeitos colaterais. É assim que a ordem da cultura global do HIV/Aids esbarra nos contextos locais e situa-se na tessitura do cotidiano das pessoas e nos modos como ordenam e gestam seus tratamentos. O tratamento diário é um dos processos da tecnologia biomédica e de cristalização social do tornar-se soropositivo. Ele acarreta aprendizados e adesão dos sentidos e experiência corporal. É um controle, como no caso das minhas interlocutoras, que se dá na vida cotidiana e no espaço doméstico. Como sinaliza Valle:

O processo de construir-se como pessoa soropositiva implica incorporar e aprender práticas terapêuticas de consumo sistemático e controlado de remédios, de leitura dos sintomas da doença e dos tratamentos sobre o corpo, dos procedimentos clínicos e tecnológicos de exames e terapias que devem ser efetuados regularmente [...] Acredito que a construção de uma pessoa soropositiva supõe, portanto, um processo de aprendizagem e educação dos sentidos e da experiência corporal, quando as mais diversas sensações (da dor ao prazer), acabam por ser reconsideradas a partir de uma nova perspectiva sobre si mesmo (VALLE, 2010, p. 43).

Tomar a testagem anti-HIV e um conjunto de aprendizados do tornar-se soropositivo, dos quais medicar-se é parte importante e integrante disso tudo, é uma interessante chave analítica para pensar na biomedicina e na ciência como uma prática de cultura global que é "reaprendida a partir das conexões e fluxos que se estabelecem tanto entre saberes e práticas globais como locais" (VALLE, 2010, p. 49). Ou, como tenho sugerido, em infraestruturas concretas na experiência social e relacional da tessitura do cotidiano das pessoas. É na forma como as interlocutoras gestam suas vidas no que tange ao tratamento para o HIV/Aids, que tem sido possível identificar aquilo de que falava Valle (2010) acerca dos limites da biomedicina como cultura global e tradição de conhecimento. Isso faz com que, mesmo havendo uma ampla circulação de valores, a cultura global das técnicas não seja homogênea, pois a ausência e/ou falta mostram a "ambiguidade de um mundo social extremamente heterogêneo, além de evidenciar as limitações da biomedicina” (p. 46).

Em meu estudo etnográfico, esses limites têm sido identificados sobretudo nas práticas cotidianas nas quais minhas interlocutoras gestam o tratamento para o HIV/Aids. A cir- 
culação de saberes que aqui temos, são formas mais gerais de Cosmovisão ocidental. Assim, o encanto gerado pelos medicamentos, explicado pelos autores Van Der Geest e Whyte (2011), é parte da representação cultural da biomedicina e suas facetas para o bem-estar. Desse modo, o movimento adotado é ir desde as tecnologias biomédicas à experiência social e relacional da pessoa e à forma como o fluxo com os medicamentos acarreta uma série de processos de significação da existência e sentimentos de prisão em seus cotidianos de saúde e doença, que dramatizam e performatizam os atos de tomar remédio.

Os atos das interlocutoras não são experiências de fracassos do medicar-se, mesmo que assim elas qualifiquem, mas são ativações e efetuações do cotidiano sociorrelacional de uma vivência mais ampla com HIV/Aids. Com as interlocutoras tem sido possível perceber como a cultura global das tecnologias biomédicas é tecida no local e no cotidiano. Em suas atitudes ambíguas e paradoxais quanto aos medicamentos, essas substâncias apresentam concretudes que geram desencantos porque são experiências que vão continuamente na contramão de enxergar os medicamentos por sua capacidade libertadora, sobretudo porque eles criam os sentimentos de prisão e fardo. Para elas, as substâncias materializam efeitos colaterais, sociais e subjetivos (BIEHL, 2008), além de processos de memória, inflexões durante a gravidez e experiências de vivências da pessoa, o que faz do encontro biográfico ${ }^{5}$ com os medicamentos em zonas que por vezes desconversam entre si (NELVO, 2017).

\section{Narrativas, pessoa e ações sociais: alguns apontamentos sobre saúde, corpo e experiência}

Ressalto, por agora, que há uma articulação analítica e reflexiva empreendida, para refletir acerca das interlocutoras como agentes do social, bem como em suas dinâmicas de saúde, doença e pessoa, que creio somar às análises já discutidas sobre a cultura global da biomedicina, para que dê suporte ao que se segue. Langdon (1995) nos apresenta as bases históricas que fundamentam o campo da antropologia da saúde para compreender a doença para além de uma unidade biológica centrada na ideia de universalidade, como discorre a biomedicina, para pensá-la ora como um produto culturalmente localizado, ora como parte de dinâmicas, atos e significações que marcam a percepção e a ação das aflições. A dimensão tomada como questão para o debate seria a cultura como dinâmica e heterogênea, e a doença como processo e experiência. Nesta visão, surgida a partir da antropologia simbólica de Geertz (1978), a cultura estaria se dando na interação entre os atores, cujo sistema seria um tanto mais fluido e aberto. Para a autora, pensar a doença sob a perspectiva antropológica é ter em mente que 
a sua interpretação faz parte de um processo acompanhado por uma gama de episódios, no qual o drama social mostra-se presente na experiência. Não é de todo desconsiderar os aspectos socioculturais. Pelo contrário, a experiência está sendo vista e entendida como processo subjetivo construído através de determinados contextos e validado pelos atores. Em outras palavras, a existência é mediada pelos outros, como uma espécie, segundo a autora, de não separação entre corpo/mente, herança cartesiana, que se expressa na dicotomia corpo/cultura.

Neste rol de discussão, é parte dos eventos das aflições o reconhecimento dos sintomas dos distúrbios, o diagnóstico e a escolha do tratamento e, por fim, a avaliação do tratamento. A doença aparece como um processo, e as experiências estão fazendo parte desde o seu início. Tomar este campo de reflexão mostra-se fundamental para as narrativas e as experiências sobre tratamento das interlocutoras da minha etnografia, pois suas trajetórias são marcadas por eventos e - como já mencionado -, longe de serem episódios históricos de um passado, nos informam sobre ações e relações sociais em seus relatos, que são constitutivos da noção de pessoa das interlocutoras. Para isso, concordo com Aureliano (2012), para quem as narrativas constituem a experiência das biografias de pessoas acometidas por diagnósticos de doenças. Em sua análise sobre diferentes espaços terapêuticos para tratar o câncer (grupos de ajuda mútua, hospitais e instituições terapêutico-religiosas), a autora nos permite pensar em como as biografias individuais emergem constantemente produzindo significados sobre a doença, seu tratamento e as ações concretas das pessoas nesse processo. Este movimento é importante para obter conhecimentos sobre as pessoas doentes que, entre outras questões, vão para além da dimensão estritamente biológica. Em um sentido próximo, Good (1994 apud AURELIANO, 2012) já havia afirmado que a narrativa seria importante para dar forma à experiência, e que é, também, um dos principais meios de conhecimento sobre uma doença.

Para Aureliano (2012) as narrativas não são apenas histórias que estão sendo contadas. Como contraponto a esta dimensão discursiva (até mesmo textual), as narrativas podem ser vistas como histórias construídas com dramaticidade em falas, gestos, atos. Em suma, elas nos comunicam a experiência da pessoa que em espaços terapêuticos pelos quais a autora realizou etnografias, está sendo negociada. Narrativas e ações estão sendo tomadas como constitutivas da biografia da pessoa doente. Seria o mesmo de dizer, portanto, que a narrativa não está afastada do campo relacional, onde as práticas e as situações sociais existem e são tecidas. A narração nesse sentido nos diz também sobre as ações sociais, a vida de determinadas pessoas e os desafios que lhes são cotidianos ${ }^{6}$.

Seguindo a linha fenomenológica, onde a experiência emerge como lócus privilegiado 
de análise, Rabelo et al., (1999) postula que ter um corpo ou ser um corpo é estar situado. Portanto, pessoas corporificadas são seres em situação. Essa perspectiva não está preocupada, mais uma vez, em tomar o corpo e a cultura como afastados, mas, sim, próximo ao que foi salientado por Csordas (2008, p. 102) acercado corpo como a "base existencial da cultura". A abordagem da experiência permite reconhecer dimensões importantes para o tema das aflições e tratamentos em que as narrativas estão entrelaçadas coma ação, pois "constituem dimensões da vida" (RABELO et al., 1999, p. 20). Em uma passagem ainda mais ilustrativa:

A narrativa não é um artifício justaposto à experiência, um adorno ou complemento acidental. Boa parte dos analistas efetivamente enfatiza que a narrativa constitui o significado da experiência. Entretanto no seu entrelaçamento com a ação, ela "o faz no curso da vida mesmo, e não apenas depois do fato, nas mãos de autores, nas páginas de livros”. (RABELO et al., 1999, p. 20).

As trajetórias das interlocutoras aqui em questão comunicam eventos vividos, mas que são presentificados na "atmosfera da vida" - noção apropriada dos ensinamentos de Das (2011). As narrativas de Luana, Suelen e Luíza sobre aos fluxos relacionais quanto aos medicamentos fazem parte do processo de construção social da realidade terapêutica (AURELIANO, 2012). A construção do tempo narrativo das interlocutoras é constitutiva de ações e situações sociais que nos revelam aspectos de significação, formas de inflexão, sentimentos de prisão e atitudes dramáticas e performáticas, no cotidiano de suas vivências com os medicamentos. As narrativas das interlocutoras dramatizam essas vivências, tanto em seu passado com eventos disruptivos e devastadores da trajetória, quanto à dimensão cotidiana das relações atuais. Isso nos releva, portanto, o potencial das narrativas como parte da composição da pessoa, e como estão constantemente inscritas no plano relacional da experiência.

Aludida essas questões, são nas narrativas que elas construíram sobre os medicamentos, que pude perceber como os efeitos colaterais, as formas de significação da realidade, conformações do fardo e prisão e abandonos das substâncias, bem como as ambiguidades e "limites" do encanto dos medicamentos e da biomedicina como cultura global são vivenciados e expressos em contornos da experiência da pessoa. Para além de simples discursos sobre os medicamentos, suas narrativas falavam sobre a construção de suas realidades terapêuticas (AURELIANO, 2012) e, portanto, entrelaça-se com as ações sociais da pessoa. Neste sentido, as narrativas trazidas doravante estão comunicando os lugares sociais no mundo de Luana, Suelen e Luíza no qual os remédios ocupam um lugar central. Assim, acredito que o fluxo relacional da pessoa com os remédios em questão comunica acerca das dinâmicas do cotidia- 
no e da ação humana, para o que se propõe, então, compreender infraestruturas concretas de experiências soropositivas junto às práticas da medicação diária, num tipo de bricolagem de vida (BIEHL, 2011). Nestas práticas, como tecerei adiante, há um sem número de desencantos por parte das interlocutoras na reunião não natural, mas, sim, relacional do encontro da pessoa com a biografia dos medicamentos (MANICA, 2012).

\section{A pessoa e seus remédios}

As narrativas sobre a gestão do tratamento para o HIV/Aids é um tensor bastante significativo para o entendimento do que se propõe uma antropologia da experiência (BRUNER, 1986) de trajetórias sociais, sobretudo no que diz respeito aos cotidianos de saúde/ doença e tratamentos (BIEHL, 2011). Para tal, faz-se importante tomá-las, no que se diz respeito às substâncias terapêuticas como constitutivas da ação social da pessoa e reveladoras sobre a infecção emergindo como um processo dinâmico e performativo da existência relacional (LANGDON, 1995) no qual as trajetórias se inscrevem em meio ao "drama social" das patologias. Em suma, é possível analisar a gestão do tratamento das interlocutoras a partir da concepção da doença como processo e experiência tal como discorreu a autora citada.

A partir do ano de 1996 o governo brasileiro implantou no SUS a Terapia de Alta Potência o que, entre outras coisas, possibilitou o aumento na qualidade de vida das pessoas infectadas por HIV/Aids (VALLE, 2010; BIEHL, 2011). Os antirretrovirais que foram contemplados com essa implantação apareceram nas narrativas de Luana, Suelen e Luíza como um dos processos formadores da condição da pessoa a partir do momento em que se "descobriram" com HIV/Aids. Para manter a doença em estágio controlado é preciso medicar-se diariamente. Em suas trajetórias há diferentes antirretrovirais, que por serem medicamentos, "são bons para pensar", por sua concretude e seu encanto como apontado por Van der Geest e Whyte (2011), bem como a sua capacidade de circulação como coisas que possuem trajetória e vida social como postulado por Manica (2012). Durante a pesquisa de campo, os antirretrovirais tiveram efeitos diversos e adequados em diferentes contextos sociais no qual a experiência da pessoa portadora do HIV/Aids se concentra. Houve, por exemplo, trocas constantes dos mesmos ${ }^{7}$. O que ocorreu, ora devido a não adaptação, ora ao momento de suas gestações, já que todas faziam uso de um tipo de medicamento (Efavirenz) que não era compatível com a formação do feto.

Luíza foi a única das interlocutoras que relatou ter dificuldades de tomar os medicamentos em seu cotidiano, alegando, ainda, que necessitava de toda uma investida racional para 
que o ato possa se concretizar para além das suas emoções. Esta última característica dela dificultaria o seu processo de tratamento. A relação que elas estabelece com os medicamentos é formador de suas subjetividades com HIV/Aids e pôde ser tecida por suas narrativas. Medicamentos saíram de cena e outros surgiram, ao passo que de alguns simplesmente não se "sabe" o nome, ou são todos chamados apenas de "remédios para tratar aquilo". Se os remédios circulam e carregam encantos em suas concretudes como afirmou Van Der Geest e Whyte (2011), condição que lhes garantem vida social (MANICA, 2012), nas narrativas desta etnografia houve um encontro entre duas trajetórias as quais gostaria de evidenciar: a das substâncias medicamentosas (antirretrovirais) com a das pessoas.

O primeiro medicamento que Luana começou a usar foi o Ritonavir. Ela se sentia um "botijão de gás" quando fazia uso dele, até que o alterou para o esquema de Biovir com Efavirenz. Contudo, ela acabou criando resistência a este último, devido às inúmeras vezes que abandonou o tratamento quando "já tinha consciência de que eram bons e importantes, mas ainda assim eu abandonava". Depois desses dois medicamentos, ela veio a conhecer o "dois em um" (Tenofovir e Efavirenz) e o Kaletra, que a acompanhou durante o período de sua gestação, já que criou resistências ao Efavirenz. Essa última combinação foi a que ela utilizou durante a gestação de Léo, que segundo narrou, lhe causou muitos enjoos. Por fim, após todos esses nomes, à época da pesquisa de campo, ela fazia uso do "tradicional”" 3x1 (Tenofovir + Lamivudina + Efavirenz).

Nas narrativas das interlocutoras foi possível captar nuances que transformam os medicamentos "bons para pensar" em suas trajetórias, por dois motivos. Primeiro, o número demasiado elevado de trocas de antirretrovirais pelo qual passaram. Segundo, o fato de terem trocado de medicamentos durante a gestação. No caso de Luana, isso apareceu como algo que veio a acarretar enjoos e abandonos dos remédios por conta disso, o que the deixou com medo de transmitir o vírus HIV para o Léo quando este ainda estava em sua barriga.

Acabou que assim, durante o tempo que eu esperei o Léo eu tinha resistências ao Efavirenz e tive que trocar para o Kaletra e o dois em um. Mas nem foi uma resistência, assim, tanto que hoje eu tomo o Efavirenz sem problema algum, sabe? A grande questão com o Kaletra é que ele me deu muitos enjoos até pelo menos o sexto mês de gravidez e eu tomava e vomitava, tomava e vomitava. Pode-se dizer que eu fiquei durante esse tempo todo sem me tratar quando esperei ele (o Léo). Eu fiquei com medo, sabe? Medo de ele acabar nascendo com HIV por isso. Mas eram muitos fortes (os enjoos). (Luana, material de campo, janeiro de 2017). 


\section{Suelen também traz situações significativas de como os remédios "são bons para pensar".}

Faço o famoso "3 em 1", Efavirenz, é esse aí pra quem conhece... Lamivudina e Tenofovir. Eu comecei acho que com o Atazanavir, um que vai na geladeira. Eu acho que é o único que vai na geladeira, só que eu não tenho certeza se é esse o nome. Passei também pelo Tenofovir e Lamivudina que vai com ele. Eu comecei com ele. Só que, um dos efeitos colaterais dele que eu tive, foi ficar com a palma da mão e os olhos muito amarelados. Aí logo eu conversei com a médica e pedi para trocar. Daí eu entrei para esse Efavirenz, que foi logo que surgiu, aliás, veio pro Brasil, na verdade. Aí eu entrei para o Efavirenz. Só que eu fiquei uns seis meses com o Efavirenz, eu engravidei. Aí eu fui pro Kaletra porque na época tinha aquela coisa que não podia tomar porque não tinha compatibilidade com o feto e podia causar má formação, era um esquema que não podia e tive que ir para o Kaletra. Aí eu tomava Kaletra com Lamivudina, eu acho. Que aí era de manhã e de noite. Fiquei só durante a gravidez. Quando a gravidez passou, eu voltei para o Efavirenz e agora como eu estou grávida de novo (risos)....Aí diz a médica que não precisa mais trocar. Eu não sei porque eu ainda vou pesquisar melhor sobre isso também. Mas elas dizem que não precisa, porque já saiu uma pesquisa que diz que o Efavirenz é da mesma família que o Kaletra, que esse negócio de má formação é tudo mentira, e até as pacientes que já tomavam algum, eles preferem não trocar para não ter resistência. Foi o que ela me explicou. Mas foi assim, uma consulta muito rápida, até porque eu só tive uma consulta pelo pré-natal. E, eu não passei por ela, foi meio que assim, da porta conversando, entendeu? Não entrei na sala e conversei com ela, eu perguntei porque eu fiquei na dúvida. Disse assim: "Ué, você não vai trocar o meu remédio?”. Aí ela falou que não precisa mais porque saiu uma nova pesquisa....Mas eu vou procurar me informar melhor sobre isso porque eu ainda nem me informei, mas ainda estou com o Efavirenz. Depois que eu tive a gravidez eu voltei pro Efavirenz e estou tomando ele até agora. Então na verdade eu já passei por três esquemas diferentes. (Suelen, material de campo, fevereiro de 2017).

Em ambas, Luana e Suelen, houve um momento de inflexão dos antirretrovirais devido a gravidez, quando faziam uso do Efavirenz e acabaram por trocar para o Kaletra. Isso é ainda mais ilustrativo na trajetória de Suelen, que àquela altura se via novamente grávida e se encontrava sem saber muito o que deveria fazer em relação ao seu atual esquema de tratamento. Van Der Geest e Whyte (2011) afirmam que os medicamentos aparecem como importantes para serem pensados em antropologia por produzirem efeitos na maneira como as pessoas se relacionam, já que eles facilitam processos simbólicos e sociais particulares de 
enfermidade. Eles "são bons para pensar", afirmam os autores, por conta de sua concretude e a objetificação de cura em sua composição. Eles trazem em seus encantos o potencial de libertação, até mesmo da figura do médico (pela possibilidade de automedicação), e intensificam a percepção da enfermidade como algo tangível. Na convivência com as interlocutoras, seja nas entrevistas, seja em outros contextos, foi possível perceber o quanto elas enxergam os remédios como importantes para seu estado de saúde e, eu diria, para mantê-las vivas a fim de poderem cuidar de seus filhos que precisam de sua presença. Aqui, porém, a concretude dos remédios não funciona como o encanto da cura da doença, mas como algo "necessário" para se viver e não ficar doente de Aids - este último estágio as demarcariam como pessoas efetivamente doentes, enquanto que ao fazerem uso de antirretrovirais diariamente lhes garantem o status de portadoras.

Ainda assim, é possível dizer que em suas narrativas há o potencial de encanto dos remédios como uma realidade, não porque isso as tiraria da vigilância de um médico, pois fica evidente no relato de Suelen que sua médica teve autoridade para trocar o seu esquema de tratamento na sua primeira gravidez, mas sim porque elas os enxergam como bons e essenciais para suas vidas. Em outras palavras, é sabido entre elas que o abandono do remédio trará complicações de saúde e esse é o encanto que teríamos aqui.

Nas narrativas sobre suas vivências com os medicamentos e as inflexões antes e durante a gravidez, podemos pensar em como suas materializações afetam as relações sociais e a experiência das pessoas. Luana e Suelen trocaram de antirretrovirais ao se encontrarem grávidas. A primeira acabou ficando meses sem conseguir medicar-se direito por conta dos enjoos que sentia, advindos da gravidez, quando fazia uso das substâncias. Suelen acabou trocando para o Efavirenz, pois o esquema anterior the causava efeitos colaterais.

Se os remédios promovem em sua concretude encantos, inclusive para as próprias interlocutoras como afirmei, eles também carregam momentos de desencantos durante a gestão terapêutica delas. Destaco os enjoos de Luana e os efeitos colaterais de Suelen como a corporificação dos seus desencantos, que de "substâncias libertadoras" tornam-se momentos limites em seu potencial de tangenciar a enfermidade, evidenciando o paradoxo das tecnologias terapêuticas da cultura biomédica para pessoas soropositivas. No caso de Luana, optar por não fazer uso dos medicamentos durante o período da gravidez, por conta dos inúmeros enjoos que estes causavam, parece-me estar de acordo com o que falava Valle (2010) acerca dos cálculos que as pessoas fazem para afinar a tecnologia biomédica aos interesses delas. Assim, é possível pensar nos "limites efetivos de incorporação das práticas biomédicas e, talvez, 
uma apropriação parcial de acordo com intenções e propósitos que deveriam se afinar com outras questões, mais particulares" (p. 44).

Aureliano (2012) ao analisar o lugar dos medicamentos nas práticas terapêuticas em um hospital espírita voltado para atendimento de pessoas com câncer em Florianópolis (SC) trouxe interessantes contribuições para se pensar a materialidade dos medicamentos e a articulação com as curas espirituais. Resumidamente falando, no campo da autora os medicamentos funcionavam como formas de materializar a prática terapêutica. Contudo, as substâncias são a inscrição da lógica biomédica e não uma prática "fundamentalmente do espiritismo" - as aspas aqui já são para se pensar em como essa questão deve ser relativizada. Tal como a autora nos mostra, e ao apropriar o conceito de mimesis de Taussing (1993 Apud AURELIANO 2012) para efeitos de compreensão dessa prática entre elementos biomédicos e do espiritismo, ela destaca que os medicamentos vão receber os seus significados a depender do contexto. Nas palavras de Aureliano:

Os medicamentos utilizados no hospital espírita em questão podem ser pensados como formas de: Materializar a prática terapêutica espírita na qual geralmente é o invisível que age sobre o visível, a energia transforma a matéria e os espíritos operam os corpos vivos. Os remédios podem inverter essa relação sem alterar seus resultados, pois a separação entre o material e o imaterial no CAPC (Centro de Apoio ao Paciente com Câncer) seria uma forma de convenção utilizada para resguardar o lugar particular e político de sistemas terapêuticos que se pretendem distintos, mas que de fato não impede aos diferentes atores que fazem parte desse cenário construir e desfazer conexões. (AURELIANO, 2012, p. 276).

Valer-me de tudo isso é fundamental para o entendimento das narrativas das interlocutoras desta etnografia e como os encantos dos medicamentos precisam ser pensados no contexto das relações de suas experiências. Para efeitos de sua concretude e capacidade de circulação por serem coisas (VAN DER GEEST e WHYTE, 2011), os antirretrovirais são apropriados e significados no contexto existencial no qual as trajetórias das interlocutoras se concentram e como elas os enxergam. Em outras palavras, tal como já formulado por Manica (2012), os medicamentos por serem coisas e circularem, são substâncias que têm vida social. Ou seja, têm determinado percurso biográfico, seja em sua formulação biomédica, seja na trajetória da pessoa que faz uso. Mas também têm vida, pois as narrativas sobre eles são aquelas existentes no social, o que permite pensá-los como modo de existência, agência. Para a autora, os medicamentos devem ser percebidos como "agentes definidores de determina- 
das dinâmicas" (MANICA, 2012, p. 185). Em outras palavras, os medicamentos teriam uma trajetória biográfica própria. Concordo com Manica de que eles têm vida social e que definem determinadas dinâmicas.

Isso posto, penso que concentrar sua vida social nas narrativas de Luana, Suelen e Luíza como componentes de suas ações sociais e a forma como estes são significados em seus contextos, mostra-se fundamental. Até mesmo para concebê-los em sua vida social e as relações da existência que giram em seu em torno. Em outras palavras, é pensar que os medicamentos têm uma trajetória e que esta é dramatizada, alterada ou simplesmente levada em conta tal como os "manuais biomédicos" da cultura global para as técnicas de gestão do HIV/Aids o classificam, na biografia da pessoa que faz uso deles. Luíza apresentou-se como aquela entre as interlocutoras deste estudo que detém maior dificuldade com os antirretrovirais. Os medicamentos, pensados aqui no contexto de sua significação existencial, são tidos como agentes de difícil nomeação para ela.

\footnotetext{
Vários esquemas. Só não lembro o nome. Os nomes são muito difíceis. Kaletra, CD4, CD8. Muito complicado, mas já tive muitos esquemas, viu. Atualmente acho que faço uso do Kaletra, Tenofovir... Tem um que é dois em um. Tenofovir com alguma coisa e tal. É porque os nomes são complicados mesmo e eu sou horrível para gravar nomes... (Romário: Tenofovir e Lamivudina?). Isso. Isso daí mesmo, entendeu? (Risos). (Luíza, material de campo, março de 2017).
}

O fato de Luíza não conseguir nomear os medicamentos é revelador do quanto não há muito interesse de sua parte em tornar aquele ato (o de saber os nomes dos antirretrovirias "de cabeça") uma coisa cotidiana. Isso se revela também por não saber ao menos o nome por completo dos medicamentos de que faz uso no tempo presente. Luíza afirmou que "os nomes são complicados mesmo". Talvez, seja uma questão da complexidade da categoria biomédica. Mas me pareceu, ao longo de sua narrativa, que para ela os antirretrovirais "são todos muito parecidos", ou, quem sabe, que todos são para a mesma função: "tratar aquilo". Diferente das outras interlocutoras que se referiam a determinado medicamento e seus efeitos colaterais e o contexto concreto de suas experiências, Luíza os trata todos como "remédios". Ou seja, enquanto Luana compreende os efeitos de "botijão de gás" com o Ritonavir, e dos enjoos causados pelo Kaletra, Luíza tem dificuldades de tomar os "remédios", sejam estes Kaletra, Tenofovir, Lamivudina e entre outros - nomes que ela listou em seu relato. Enquanto Suelen reconhece que o Atazanavir vai na geladeira e que o Tenofovir e o Lamivudina a deixava com a palma da mão amarelada, Luíza considera o CD4 e o CD8 um tipo de remédio. 
Esta última consideração também foi algo do campo relevante de ser destacado, pois os dois supostos antirretrovirais citados são na realidade exames de sangue específicos para o tipo de patologia em questão e não medicamento para ser ingerido pela via oral.

O que marca a narrativa de Luíza é a maneira como a medicação apareceu como um ato de dramatização, ao passo que estabelece relações entre as pessoas em seu cotidiano familiar, sob o horário e as táticas adotadas para fazer uso:

Agora, agora, agora umas semanas atrás eu estou indo mais pelo lado da razão do que da emoção. Porque se eu passei praticamente cinco anos indo pela emoção e me ferrei, entendeu? Hoje é tranquilo. Eu tô um pouco assim, né? Mas eu tô me cuidando. O Ruan não precisa, graças a deus, com ele ta super tranquilo mesmo. Pretendo ser melhor do que está sendo agora. De tomar os remédios todo dia sem ter nenhum problema. E tipo, uma coisa que você pode levar três minutos eu levo vinte minutos tomando o remédio. Eu fico bastante tempo na cozinha. Eu fico olhando pro remédio e fico imaginando ele descendo agarrando...nojo disso. A médica fala: "Toma com suco, alguma coisa”. Fui tomar com guaracamp quando era mais nova. Eu senti o remédio na minha garganta, me engasguei, o remédio saiu pelo nariz, já tem anos que eu não bebo guaracamp, se eu sentir o cheiro eu sinto o cheiro do remédio, foi bizarro. E tipo assim, eu quero chegar numa fase e falar assim: "Ah, tá na hora de tomar o remédio e ir lá e tomar tranquilo". Mas não, se eu botar ele assim na minha mão [apontando para a mão direita] ou ver alguém tomando um remédio já me dá uma coisa, assim, que até quando eu namorava o Carlos, ele tomava remédio pra dor de cabeça, eu fazia ele escovar os dentes pra me beijar porque é um nojo horrível. Me dá até uma coisa aqui só de falar [...] Tem gente que diz que bebe até com cerveja. Eu mal consigo beber com água, quem dirá com cerveja. Não desce, não desce, não desce. Tem um amigo que engole com a banana. Se eu fizer isso eu nunca mais vou querer olhar pra banana. Eu tenho trauma de remédio. Se eu tiver que tomar, mesmo se for assim dipirona que você tem que tomar por sete dias, anti-inflamatório.... São sete dias? Eu tomo três ou quatro e depois eu esqueço. Dipirona pra dor de cabeça eu durmo e só tomo de novo se eu acordar com dor de cabeça, aí eu tomo, fora isso eu fico com dor de cabeça tranquilo, não engulo remédio (risos). E eu quero cuidar mais disso, entendeu? Ver que o remédio não é um bicho. Minha mãe que arruma o meu remédio. Eu só pego nele assim rápido, faço menos barulho possível e coloco lá no armário porque se ficar na minha mão eu jogo fora. Tem que engolir rápido. E quando bate no dente então? Aff....Só de pensar que daqui a pouco tem que tomar, porque é na janta, dá até um negócio na boca com vontade de vomitar. Mas eu tenho que trabalhar isso e pensar: "porque isso não 
pode acontecer e sim eu tenho que levar de boa, não vou vomitar, não vai bater no meu dente, não vai passar na garganta, encostar na garganta" Aí eu consigo tomar de boa. Acho que eu mesmo que aterrorizo o remédio, porque é tranquilo tomar um remédio, eu que não consigo. Sou muito louca. (Luíza, material de campo, março de 2017).

No estudo etnográfico realizado por Valle (2010) essa dinâmica da esfera do privado, das relações que se estabelecem em torno do tratamento, bem como as estratégias para ocultar os medicamentos e o estigma que eventualmente pode advir deles apareciam como uma cultura material da gestão do tratamento. No caso da interlocutora, suas estratégias estão comunicando um cotidiano relacional, no qual uma série de objetos, pessoas e situações aparecem entrecruzando suas atitudes diárias de não conseguir fazer o uso correto dos medicamentos. Enquanto Luana e Suelen ao se referirem aos antirretrovirais traziam em suas narrativas eventos de reflexão, de quando passaram a fazer uso de um ou mais medicamentos, os desafios, os muitos nomes, Luíza não fez menção a um evento em específico que fosse próximo das demais interlocutoras. Há passagens em sua narrativa, como o ato de não tomar mais Guaracamp porque se lembra do cheiro dos remédios, que pode ser entendido como um momento marcante. O diálogo de Luíza sobre o uso dos medicamentos não é tecido a partir de um evento como resistência imunológica, enjoos e partes do corpo amareladas, mas como uma composição total de sua materialização. Ou seja, ela traz as substâncias medicamentosas para o plano de sua ação social, mesclando sua narrativa com eventos do passado e dialogando com o tempo presente, até mesmo o tempo do presente etnográfico quando veio a mencionar que se mostrava aflita somente por saber que àquela hora - a que produziu o relato acima - aproximava-se de uma repetição daquele ato que, segundo mencionou, desperta nela uma sensação de "nojo".

Apesar da recusa e asco em usar os medicamentos, Luiza afirmou que hoje estaria tudo mais "tranquilo". Ela se referia ao fato de estar tentando restabelecer a prática cotidiana de tomar a medicação. É ilustrativo em seu relato trazido o esforço para melhorar ainda mais essa prática.

Fazer uso do medicamento é algo que Luíza reconhece que pode ser resolvido em poucos minutos, mas segundo contou, leva cerca de 20 minutos para tal. É preciso um forte engajamento emotivo para o ato de medicar-se. Ela fica muito tempo na cozinha (onde armazena e toma os medicamentos) tentando controlar as sensações que o uso do medicamento desperta, tal como imaginá-lo descendo e agarrando em sua garganta. Outro aspecto que também pode ser destacado como narrativas do tempo é a prática da comparação com 
um futuro próximo e desejado quanto ao ato: "Ah, tá na hora de tomar o remédio e ir lá e tomar tranquilo", é uma das situações hipotéticas do por vir desejada pela interlocutora. Neste ponto, é importante fazer uma alusão com os ensinamentos de Valle (2010), que ao valer-se dos escritos de Becker (1973), frisou que o processo de tornar-se soropositivo acarreta uma série de aprendizados para a pessoa. Tomar o medicamento no horário correto e diariamente, não esquecer e também dispor em locais refrigerados aqueles que houver necessidade, fazem parte dessas práticas. À luz dos relatos da interlocutora em questão é perceptível que estes aprendizados corroboram as expectativas das técnicas da biomedicina como cultura global, uma vez que Luíza traz situações que a afligem e são relatos não de liberdade em relação aos medicamentos, mas sim de momentos de intenso engajamento e dificuldade por parte da pessoa.

A dificuldade de Luíza em medicar-se não está descolada da sua dificuldade em reconhecer-se como portadora daquilo, para usar a expressão com a qual ela se refere ao HIV/ Aids. Em suas narrativas sobre a "descoberta" do HIV/Aids", ela iniciava fazendo menção ao fato de ter dificuldades de tomar remédio. Evidencia-se em sua fala os aspectos ligados à materialidade do medicamento, ao mencionar a sensação dele descendo pela garganta, por exemplo. Tomar o remédio é também a materialização que aquilo existe e é parte da pessoa. Ou seja, a concretude do medicamento é a atualização cotidiana da condição sorológica em sua vivência e, portanto, é uma significação existencial de seu processo de saúde e doença. O que não quer dizer que para Luana e Suelen isso também não apareça, contudo, o significado que os "remédios" recebem pela pessoa que faz o seu uso é a prova do quanto ele é interpretado de uma forma muito peculiar.

Isto chega ao ponto de que para qualquer outro tipo de remédio (analgésicos, por exemplo) a maneira como a sua experiência se dá com eles é a mesma, similar a sua reação para os medicamentos que são para tratar aquilo. A concretude com que compõe a substância como coisa não aparece aqui ligada à lógica da liberdade (para o uso do medicamento e sua manipulação), mas justamente como aquilo que a aprisiona, que faz o ato de medicar-se ser sentido como uma situação traumática. Ao lançar olhares para as experiências da interlocutora, há outras narrativas possíveis para conceber os medicamentos, que não por seus encantos, mas sim por formas concretas e existenciais de desencantos. A partir dos seus relatos eles aparecem como um fardo e a atualização diária de uma série de dificuldades que a mantém numa situação paradoxal quanto às tecnologias da cultura biomédica em sua gestão para o tratamento do HIV/Aids: por um lado, ela não consegue utilizar os medicamentos, e não 
fazer o uso parece ser o caminho mais fácil e algum tipo de "alívio". Por outro, isso acarreta danos para seu estado de saúde, podendo gerar enfraquecimento do Sistema Imunológico e em doenças oportunistas, podendo, inclusive, chegar ao estágio de Aids.

O que é interessante na narrativa de Luíza, é que, por um lado, ela contrapõe o que foi proposto por Van Der Geest e Whyte (2011) e permite repensar as noções de liberdade e de concretude do medicamento visto a partir do seu encanto. Contudo, por outro lado, no desafio com o qual as narrativas são tecidas, podemos perceber que a interlocutora reconhece ser esse o melhor caminho a ser seguido e que, entre outras coisas, ela precisa melhorar essa situação de dificuldade cotidiana. Desta forma, mesmo que a materialidade dos antirretrovirais seja vista com desencanto - não à toa é a noção central para este artigo - na experiência concreta e existencial da pessoa, no plano ideal de seus desejos, ela é vista como algo necessário, pois parece ser importante para controlar sua enfermidade.

Outra situação social que ainda merece ser destacada em Luíza é a composição física do cenário e a quantidade de atores que mobiliza, pensando aqui na ideia da cultura material na organização da gestão do tratamento (VALLE, 2010). É a mãe quem arruma os seus remédios, ao passo que ela os pega rápido e sem fazer barulho. Depois do ato concluído, ela os devolve para o armário. Caso isso não ocorra, o que Luíza nos conta é que possivelmente virá a se desfazer dos remédios, em outras palavras, os jogará fora. Essa composição do ato da medicação mostra-se relevante para se pensar em como nesses atos diários, em casos de doenças crônicas, são estabelecidas relações sociais, mesmo em uma situação supostamente individual. Afinal, é apenas Luíza que engole os seus remédios. Em outras palavras, a composição física e a mobilização dos atores em torno dos medicamentos de Luíza fazem parte do fluxo relacional de gestão do tratamento.

Luíza afirma também que atualmente estaria indo mais pelo lado da raz̃ão do que da emoção $0^{10}$. Para ela, agir pela emoção seria prejudicial para si, fazendo com que viesse a não conseguir engolir os remédios que lhes são essenciais e necessários, ou mesmo jogá-los fora. Aqui, utilizar da emoção em um tipo de tratamento como este em que se espera controlar aquilo é um dos fatores que dificultam o seu processo. Modo análogo ao que foi discutido por Aureliano (2014) no tratamento com curas espirituais para o câncer, no qual as emoções são ora as explicações para a doença, ora fatores diversos que dificultam à terapêutica. Contudo, no campo da autora, as emoções ainda apareciam com o seu potencial de engajamento com o hospital em questão, o que era valorizado para se ter adesão dos pacientes ao tratamento, pois os impactos emocionais são capazes de mobilizar as pessoas para a ação 
e o engajamento na cura (AURELIANO, 2014, p. 72). Ainda que Luíza tome a investida da razão como o que desmistificaria o "remédio como um bicho", o que destaco de suas dramatizações e as atitudes de dificuldades na gestão do tratamento é justamente um engajamento emocional para a realização dos atos do medicar-se, inclusive ações tidas como de sucesso, quando mesmo com o tempo demasiado elevado do processo de medicação ela consegue desenrolar a situação. Neste sentido, ela afirma: "mas eu tenho que trabalhar isso e pensar: 'porque isso não pode acontecer e sim, eu tenho que levar de boa, não vou vomitar, não vai bater no meu dente, não vai passar na garganta, encostar na garganta'. Aí eu consigo tomar de boa".

Dessa forma, pode-se afirmar que viver com aquilo, e lidar com os seus desafios constantes é também produzir um tipo muito peculiar de engajamento emocional que aqui apareceu na forma como a interlocutora faz e lê a gestão terapêutica para o HIV/Aids em seu processo de significação existencial. Ora como o que supostamente dificultaria o seu processo, ora com as dramatizações para efeitos de realizações. Dramatizações estas que aparecem no espaço físico, nas relações estabelecidas com as pessoas do lar, na maneira como se pensa minutos antes do ato de tomar o remédio - ele não vai "bater na garganta" -, e, por fim, de ser potencializado nas ações de reflexão, de um trabalho até mesmo "préterapêutico" de conversão da ideia tida do ato em si - como o trecho acima destacado, já que Luíza conversa com ela mesma durante muito tempo antes de tentar engolir seus remédios.

Por fim, penso que as tensões e ambiguidades paradoxais das tecnologias da biomedicina como cultura global no caso de Luíza, expressas na infraestrutura concreta de sua gestão terapêutica, que pode ser abstraída para a vivência com aquilo como um todo, é a materialização do quanto sua trajetória é marcada por uma dinâmica que transforma o HIV/ Aids, em sua imensidão de dificuldades, em parte da composição de sua existência social.

Considerar os desafios que tornam os cotidianos dessas pessoas precários (BUTLER, 2009, 2011), com as inúmeras trocas de antirretrovirais, advindas de inflexões manifestadas no corpo e as dramatizações de desencantos e sentimentos de prisão na prática terapêutica, requer reconhecer que são partes de agenciamentos, resistências ou escolhas, que trazem novos contornos para suas biografias. Entre esses contornos inscreve-se o reconhecimento de que são processos sociais, que o sofrimento é até mesmo uma realidade diária - como Luíza muito bem evidencia em seus relatos - mas que há um engajamento por detrás de suas narrativas; até mesmo no que se refere ao ato de contar sua história para uma outra pessoa, como foi comigo, um pesquisador tentado a ouvi-las. 
Então, as pessoas precisam falar mais sobre isso e falar as coisas que estão presas dentro delas porque eu fiquei dois anos sufocada com o sentimento preso de rancor, ódio, desprezo, raiva, e quando eu me explodi eu falei: "Não aguento mais". Se eu tivesse conversado com alguém antes, ou tivesse ouvido alguém que passou pela minha vida eu não teria passado por isso e sofrido também. (Luíza, material de campo, março de 2017).

\section{Considerações finais: é só não desistir de mim!}

Ao longo deste artigo, procurei refletir acerca da prática cotidiana da gestão do tratamento terapêutico efetuado por três jovens mulheres e mães jovens soropositivas, de camadas populares da cidade do Rio de Janeiro. Os medicamentos de que elas faziam uso ao longo da pesquisa de campo ocupavam lugares centrais em suas trajetórias e facilitavam uma série de processos sociais, cujo ato do medicar-se aparecia como um fluxo relacional. Minha intenção foi perceber quais são os embates advindos destas práticas e como os medicamentos resultam em momentos de inflexões, processos de significação existencial e sentimentos de prisão por parte das interlocutoras. Desse modo, partindo-se das práticas das interlocutoras é possível compreender os efeitos ambíguos e paradoxais das técnicas biomédicas como cultura global para o HIV/Aids. À luz dos relatos trazidos, pude analisar a forma como gestam o tratamento a partir dos "limites da biomedicina como cultura global e tradição de conhecimento" (VALLE, 2010, p. 46).

Esse movimento pôde ocorrer porque parti de infraestruturas concretas na tessitura do cotidiano das pessoas quanto à gestão terapêutica para o HIV/Aids. Dentre esses "limites" encontrou-se outras narrativas possíveis para o encanto e à liberdade advindas da concretude dos medicamentos numa Cosmovisão ocidental (VAN DER GEEST e WHYTE, 2011). Ao valer-se da precariedade de vidas humanas e dos efeitos reais que os medicamentos, sejam em inflexões expressas no corpo, sejam em sentimentos de prisão que eles geram, as interlocutoras corroboram essas formas analíticas nas quais os medicamentos são vistos. Para além de as encantarem, a gestão de seus tratamentos materializa desencantos terapêuticos.

Mais do que repetir tudo o que foi dito ao longo do artigo, penso que essa guisa de conclusão pode ainda ser um espaço de reflexão quanto ao tempo presente das interlocutoras. A frase que aludo como título destas considerações finais é de Luíza e ela foi dita quando eu estava dedicado à escrita deste texto. Como o de costume, trocamos diálogos esporadicamente e em uma de nossas conversas por rede virtual ela mencionou que desejava me contar algo que a estava deixando muito triste e pensativa. Luíza relatou estar sendo uma fase difícil 
de sua vida. Encontra-se desempregada, seu filho está crescendo e é mãe solteira. Uma amiga que considerava muito em sua rede de relações de amizade procurou uma terceira pessoa para saber o porquê de ela postar inúmeras mensagens de morte em seu Facebook. Sua condição sorológica foi então revelada nessa ocasião.

Segundo me contou, o pai de Ruan foi procurado e confirmou toda a situação e disse, inclusive, que não a deixava quando namoravam porque tinha medo de que ela acabasse por suicidar-se. Se até aí o que a interlocutora me contava já era de todo algo demasiado sério, ela ainda veio a dizer que desde quando me deu a primeira entrevista para esta etnografia jamais retornou a fazer uso de seus remédios. Fiquei muito preocupado com isso e quis saber um pouco mais de suas dificuldades, que de certa forma estavam para além do tempo das narrativas do campo etnográfico que alicerçou este artigo.

Parte dos eventos dramáticos atuais de sua condição que foi relevada para outras pessoas é um dos motivos pelos quais não consegue mais medicar-se. A outra parte é porque ela mesma não consegue, por tudo o que foi mostrado nesse texto, fazer uso das substâncias. Luíza pediu-me para ficar em "seu pé", apenas alertando sobre a importância de tomar os remédios todos os dias, pois as pessoas já desistiram dela. Ela então me fez um pedido: É só não desistir de mim! Desde aquele dia pergunto a ela algumas vezes durante a semana sobre sua medicação. Mesmo que eu a indague e não tenha desistido dela, como de sua vontade, seu uso ainda não é regular.

Para efeitos conclusivos, todo esse enredo de sua vida no tempo atual em que eu mesmo acabo de certa forma participando de sua temporalidade na gestão do seu tratamento, é a materialização do quanto os relatos tecidos neste artigo são partes das ações sociais das interlocutoras e constroem seus lugares no mundo.

Destaco que ao lidar com pessoas e levar em conta suas práticas terapêuticas cotidianas essa etnografia estará sempre em movimento e construção. Aludo isso porque suas experiências também estão e mesmo que aqui eu tenha visibilizado os relatos tecidos no presente etnográfico reconsiderá-los é um compromisso da análise antropológica. Assim, é possível estar atento aos cálculos e redefinições do cotidiano das interlocutoras fazendo com que suas existências não sejam esquecidas. Por agora, espero que essas trajetórias contribuam para os estudos sobre antropologia da saúde e experiência de adoecimentos, e especificamente neste texto, em como o encontro da biografia da pessoa com a dos remédios é uma zona relacional que merece atenção. No presente fluxo, se entrecruzam desejos e fracassos, liberdades e prisões, encantos e desencantos, fardos e resistências. Assim, são vidas em constante disputa 
social, circunscritas em precariedades que requer o objetivo mesmo da etnografia: o da reconocibilidad ontológica dessas interlocutoras como pessoas e agentes do social (BUTLER, 2009).

\section{Notas}

1. Por conta dos limites temáticos do artigo, não aprofundei o detalhamento da vida das interlocutoras, limitando-me somente em como os medicamentos são por elas experienciados. Eventualmente, pontuei outros fatores no decorrer do artigo que articule com a leitura dos medicamentos. Sugiro que os remédios devem estar inseridos em uma ampla gama relacional na qual estão inseridas (gênero, família, conjugalidades etc.). Friso que por vezes irei me valer da categoria "remédio" porque foi a maneira como corriqueiramente elas se referiam. Assim, "remédio" é uma categoria nativa. Maiores detalhes sobre elas poderão ser acessados na minha etnografia intitulada. "Tecendo Narrativas e Emoções: Uma etnografia sobre trajetórias de mulheres com HIV/Aids” (NELVO, 2017).

2. Um dos nomes das interlocutoras é verdadeiro, pois foi um pedido da mesma à ocasião da pesquisa de campo. Os nomes das demais são fictícios e de escolhas exclusivamente minhas.

3. As entrevistas duraram em média de quatro a seis horas.

4. Essas oportunidades me fizeram empreender outro estudo etnográfico, cujo foco principal recaiu sobre a análise antropológica de "casos jurídicos de transmissão do HIV"'. A partir das discussões tecidas nos referidos movimentos etnográficos, obtive informações acerca destes casos e procurei adentrar os documentos burocráticos junto à justiça brasileira. O que concluiu-se é que há uma espécie de "enredo das condenações" de pessoas soropositivas, na qual sexualidade, responsabilidade e risco acionam-se como marcadores da diferença no âmbito jurídico destas condenações, que permite abrir um leque de moralidades sociais existentes (NELVO, 2017).

5. Um dos apontamentos teóricos para tomar os medicamentos por sua capacidade de gerar encantos, tais quais empreendo aqui, é tomá-lo como tendo biografia, concretude e eles mesmos facilitando processos e dinamizando relações. Adiante, trabalharei melhor essa ideia da "vida social dos medicamentos" (MANICA, 2012) a fim de compreender o fluxo relacional das minhas interlocutoras também como um encontro biográfico.

6. É uma noção muito próxima da perspectiva contextualista para se entender as emoções postulado pelas autoras Abu-Lughod e Lutz (1990). Ao apropriarem o discurso, advindo dos ensinamentos de Foucault, como aquilo que manteria com a realidade uma dimensão de formação emotiva, penso que seja algo relevante, até mesmo para tomar as narrativas como "gramáticas emotivas", a dimensão tal como tenho dito de que a narração não é afastada da ação.

7. Cabe destacar que antes da implementação da Terapia de Alta Potência no SUS, o medicamento mais comum, utilizado pelas pessoas, era o AZT, além do que, mesmo no início da resolução da Lei n ${ }^{\circ} 9.313$ o número de medicamentos que os portadores utilizavam era demasiado alto. Fato curioso, é que atualmente as pessoas infectadas iniciam com o tratamento conhecido por " $3 x 1$ 1", ou seja, apenas um comprimido. Esse esquema é considerado o básico. Dito isso, um dos movimentos analíticos que me chamou a atenção durante à época da pesquisa de campo, foi justamente o fato de elas relatarem muitos antirretrovirais, o que por vezes me deixava curioso por conta dos avanços nos tratamentos biomédicos e o número elevado de trocas pelas quais passavam.

8. Um dos processos de gestão do tratamento para o HIV/Aids por marte da interlocutora, é ocultar a palavra HIV/ Aids. Luíza forja a categoria aquilo para referir-se à condição sorológica. Quando diz sobre os medicamentos também discurso com a categoria forjada. No mesmo sentido, como ficará evidente ao longo de suas narrativas, ela chama os antirretrovirais todos de maneira genérica por "remédios". Para ela, independendo do nome, da cor etc., todos eles 
são remédios para algum fim.

9. Essas narrativas podem ser mais bem visualizadas em NELVO (2017).

10. A oposição razão versus emoção foi central nas narrativas das interlocutoras e também o é para os objetivos deste artigo, uma vez que Luíza frisava bastante essa relação ao aludir suas atitudes em relação à gestão do tratamento. Não à toa, ao longo da presente análise tenho me valido de formas cotidianas da interlocutora no que tange aos atos de tomar os medicamentos, é refletido sobre formas de dramatizações. O campo da antropologia das emoções é central para a construção dessa etnografia, e é a chave analítica tal qual reflito sobre atitudes morais de resistências por parte das interlocutoras. Baseio-me, sobretudo, na perspectiva que toma as emoções em seu pragmatismo, as entendendo como práticas sociais, a partir de "discursos emocionais" (ABU-LUGHOD e LUTZ, 1990). Deste modo, o que destaco no presente artigo é como as utilizações dos discursos de emoções permitem pensar em práticas de engajamento e resistência, frente a lidar com os desafios e sentimentos de "prisão" em relação aos medicamentos. Por conta das limitações do artigo, não irei me aprofundar tanto teórica quanto analiticamente neste ponto. Todavia, deixo como citações autores tais quais, neste sentido, os utilizo (ABU-LUGHOD e LUTZ, 1990; REZENDE e COELHO, 2010).

\section{Referências}

ABU-LUGHOD, Lila; LUTZ, Catherine. Introduction: emotion, discourse and the politics of everyday life. In: LUTZ, Catherine; ABU-LUGHOD, Lila. (Orgs.). Language and the politics of emotion. Cambridge: Cambridge University Press, 1990.

ABU-LUGHOD, Lila. Writing women's wolrds: Bedouin stories. Berkeley: University of California Press, 1993.

ALVES, Paulo Cesar; RABELO, Miriam Cristina. Antropologia da Saúde: traçando identidade e explorando fronteiras. Rio de Janeiro: Fiocruz, 1998.

AURELIANO, Waleska de Araújo. As pessoas que as doenças têm: entre o biológico e o biográfico. In: GONÇALVES, Marco Antônio; MARQUES, Roberto; CARDOSO, Vânia Ziká. (Org.). Etnobiografia: Subjetivação e etnografia. Rio de Janeiro: Editora 7 Letras, 2012.

. Sofrer na Alma, Sentir no Corpo: Interfaces contemporâneas entre emoções, espiritualidade e saúde. Revista Brasileira de Sociologia da Emoção, Paraíba, v. 13, n.37, Abr, p. 59-79, 2014.

AZIZE, Rogério L. A química da qualidade de vida: Uso de medicamentos e saúde em classes médias urbanas brasileiras. Dissertação (Mestrado em Antropologia Social) - Programa de Pós-graduação em Antropologia Social, Universidade Federal de Santa Catarina, Florianópolis, 2002.

- Antropologia e medicamentos: uma aproximação necessária. R@U: Revista de Antropologia Social dos alunos do PPGAS-UFSCAR, São Carlos, v. 13 n. 1, p. 134-139, 2012. 
BECKER, Howard. Outsiders: Studies in the Sociology of Deviance. New York: The Free Press, 1973;

BIEHL, João. Will to live: AIDS Drugs and Local Economies of Salvation. Public Culture. v. 18, n. 3, Durham, p. 457-472, 2006.

- Antropologia do devir: psicofármacos, abandono social, desejo. Revista de Antropologia, São Paulo, v. 51, n. 2, p. 413-449, 2008.

- Antropologia no campo da saúde global. Revista Horizontes Antropológicos, Porto Alegre. v. 17, n. 35, p. 257-296, 2011.

BRUNER, Edward M. Experience and Its Expressions. In: TURNER, Victor; BRUNER, Edward M. (Orgs.).The Anthropology of experience. Urbana e Chicago: Universityof Illinois Press, 1986.

BUTLER, Judith. Marcos de guerra: las vidas lloradas. Buenos Aires: Paidós, 2010.

- Vida Precária. Contemporânea, Florianópolis. n. 1, p. 13-33, 2011.

CSORDAS, Thomas. Corpo, Significado, Cura. Porto Alegre: UFRGS, 2008.

CUNHA, Claudia. Jovens "vivendo com HIV/Aids": A (con)formação de sujeitos em meio ao embaraço. Tese (Doutorado em Antropologia Social), Programa de Pós-Graduação em Antropologia Social, Museu Nacional, Universidade Federal do Rio de Janeiro, Rio de Janeiro, 2011.

DANIEL, Herbert; PARKER, Richard. A terceira epidemia. São Paulo: Iglu, 1991.

DAS, Veena. $\mathrm{O}$ ato de testemunhar: violência, gênero e subjetividade. Cadernos Pagu, Campinas, (37), julho-dezembro, p. 09-41, 2011.

FOUCAULT, Michel. Vigiar e Punir. Petrópolis: Vozes, 1987.

FLEISCHER, Soraya; FERREIRA, Jaqueline. Apresentação. In: FLEISCHER, Soraya; FERREIRA, Jaqueline (Orgs.). Etnografias em serviços de saúde. Rio de Janeiro: Garamond, 2014.

GEERTZ, Clifford. A Interpretação das Culturas. Rio de Janeiro: Zahar, 1978.

LANGDON, Esther Jean. A doença como experiência: A construção da doença e seu desafio para a prática médica. Palestra oferecida na Conferência 30 Anos Xingu, Escola Paulista de Medicina, São Paulo, 1995.

MANICA, Daniela Tonelli. A vida social dos medicamentos: etnografias e escolhas. R@U: 
Revista de Antropologia Social dos alunos do PPGAS-UFSCAR, São Carlos, v.13 n.1, p. 179-188, jan/ jun, 2012.

MARCUS, George. Ethnography in/of the world system: The emergence of multi-sited ethnography. Annual Review of Anthropology, n. 24, p. 6-14, 1995.

MAUSS, Marcel. Uma categoria do espírito humano: a noção de pessoa, a de "eu". In: MAUSS, Marcel. Sociologia e Antropologia. São Paulo: Cosac Naify, 2015.

MONTEIRO, Simone; VILLELA, Wilza; FRAGA, Livia; SOARES, Priscila; PINHO, Adriana. The Dynamics of the productionof AIDS-related stigma among pregnant women living with HIV/AIDS in Rio de Janeiro, Brazil. Cadernos de Saúde Pública, Rio de Janeiro, v. 32, n. 12, p. 1-11, 2016.

NELVO, Romário Vieira. Tecendo Narrativas e Emoções: Uma etnografia sobre trajetórias de mulheres com HIV/Aids. Monografia de Conclusão de Curso (Bacharelado em Ciências Sociais) - Instituto de Ciências Sociais. Universidade do Estado do Rio de Janeiro, Rio de Janeiro, 2017.

. O Enredo das Condenações: Uma etnografia entre documentos e "justiçac" acerca de casos de transmissão do HIV. Revista Idealogando, Recife, v. 1, n. 2, p. 102- 121.

ORTNER, Sherry. Poder e Projetos: Reflexões sobre a agência. In: GROSSI, Miriam Pillar; ECKERT, Cornelia; FRY, Peter (Orgs.). Conferencias e Práticas antropológicas. Blumenau: Nova Letra, 2007.

RABELO, Miriam Cristina; ALVES, Paulo César; SOUZA, Iara Maria (Orgs.). Experiência de doenca e narrativa. Rio de Janeiro: Fiocruz. 1999.

REZENDE, Claudia; COELHO, Maria. Antropologia das Emoçōes. Rio de Janeiro: FGV, 2010.

SONTAG, Suzan. Aids e suas metáforas. São Paulo: Companhia das Letras, 1989.

VALLE, Carlos Guilherme O. Identidades, Doença e Organização Social. Horizontes Antropológicos, Porto Alegre, ano 8, n. 17, p.179-210, jul, 2002.

- Corpo, Doença e Biomedicina: Uma análise antropológica de práticas corporais e de tratamento entre pessoas com HIV/AIDS. Vivencia, Natal, n. 35, p. 33-51, 2010.

VAN DER GEEST, Sjaak; WHYTE, Susan Reynolds. 2011. O encanto dos medicamentos: metáforas e metonímias. Sociedade e Cultura, Goiânia, v.14 n.2, p. 457-472, jul/dez, 2011. 


\title{
Biomedicine, treatment management and disenchantment: experi- ences of HIV positive women in Rio de Janeiro
}

\begin{abstract}
With the advancement of biomedical technologies for the treatment of HIV/AIDS, increased living quality became a possibility for people living with the virus, in an opposite scenario from the 1980s, when the diagnosis was like a death sentence. On the other hand, becoming HIV-positive requires changes in a range of everyday habits, with daily medication becoming a part of this process. In this article, I analyze the side effects, the social and subjective consequences of medicalization and treatment management in social trajectories. What is of interest here is the interweaving between life stories and the materiality and concreteness of pharmacological drugs. Therefore, I make use of the anthropological analysis of the journeys of three young women who are seropositive mothers, from the popular class of the city of Rio de Janeiro. From the analysis of how people manage their daily routine, it has been possible to understand the ambiguities and limits of biomedicine as a global culture, since the medication for them implies processes of meaning of experience, moments of inflection and feelings of imprisonment. Thus, their experiences materialize the real effects of technologies in the disenchantment of therapy in the HIV/Aids management of the treatment, as well as open a door to think about medication beyond the analytical key of freedom and enchantment in a Western worldview.
\end{abstract}

Key words: Biomedicine; Treatment management; Anthropology of health; HIV/AIDS; Medicines.

Recebido em 28 de julho de 2017. Aceito em 13 de março de 2018. 